NBER WORKING PAPER SERIES

\title{
THE CHARACTER AND DETERMINANTS \\ OF CORPORATE CAPITAL GAINS
}

\author{
Mihir A. Desai \\ William M. Gentry \\ Working Paper 10153 \\ http://www.nber.org/papers/w10153
}

\section{NATIONAL BUREAU OF ECONOMIC RESEARCH 1050 Massachusetts Avenue Cambridge, MA 02138}

December 2003

This paper was prepared for the Tax Policy and the Economy Conference in November 2003 in Washington DC. We thank John Graham, Jim Hines and Jim Poterba for helpful comments and Sean Lubens for helpful research assistance. Desai thanks the Division of Research of Harvard Business School for generous funding. The views expressed herein are those of the authors and not necessarily those of the National Bureau of Economic Research.

(C2003 by Mihir A. Desai and William M. Gentry. All rights reserved. Short sections of text, not to exceed two paragraphs, may be quoted without explicit permission provided that full credit, including $\mathbb{C}$ notice, is given to the source. 
The Character and Determinants of Corporate Capital Gains

Mihir A. Desai and William M. Gentry

NBER Working Paper No. 10153

December 2003

JEL No. H25, G32, G38, K34, E62

\section{ABSTRACT}

This paper analyzes how corporate capital gains taxes affect the capital gain realization decisions of firms. The paper outlines the tax treatment of corporate capital gains, the consequent incentives for firms with gains and losses, the efficiency consequences of these taxes in the context of other taxes and capital market distortions, and the response of firms to these incentives. Despite receiving limited attention, corporate capital gain realizations have averaged 30 percent of individual capital gain realizations over the last fifty years and have increased dramatically in importance over the last decade. By 1999, the ratio of net long-term capital gains to income subject to tax was 21 percent and was distributed across a variety of industries suggesting the importance of realization behavior to corporate financing decisions. Time-series analysis of aggregate realization behavior demonstrates that corporate capital gains taxes impact realization behavior significantly. Similarly, an analysis of firm-level investment and property, plant, and equipment (PPE) disposal decisions and gain recognition behavior similarly suggests an important role for these taxes in determining when firms raise money by disposing of assets and realizing gains.

Mihir Desai

Morgan 363

Harvard Business School

Boston, MA 02163

and NBER

mdesai@hbs.edu

\author{
William M. Gentry \\ Department of Economics \\ Williams College \\ Fernald House \\ Williamstown, MA 01267 \\ and NBER \\ william.m.gentry@williams.edu
}




\section{Introduction}

Analyses of the impact of the tax system on corporate behavior typically emphasize the role of the corporate income tax in altering firm financing and investment decisions. These financing and investment decisions, in turn, have been shown to depend critically on the wedge between the costs of internal and external finance. One obvious and important source of internal finance, aside from retained earnings, is the disposal of assets and investments. The role of taxes in influencing these types of financing decisions may be non-trivial given the system of taxing corporate capital gains and the distortions that arise from costly external finance.

Despite the potential importance of asset sales as a source of financing corporate investment, relatively little research has been done on how corporate capital gains taxes might affect asset sales. Analyses of capital gains taxes have focused almost exclusively on the realization behavior of individuals with particular attention on the revenue consequences of changing capital gains tax rates and on the impact on risk taking and expected asset returns. The relative oversight of the corporate capital gains tax system is surprising given the substantial volume of corporate capital gains - U.S. corporations realized $\$ 146.5$ billion of net long-term capital gains, or 21 percent of their income subject to tax, in 1999 - and the potentially distortionary impact of these taxes stemming from interactions with capital market imperfections. In this paper, we address this oversight by detailing U.S. tax policy toward corporate capital gains, characterizing the nature and distribution of corporate capital gain activity, and examining the effect of these taxes on the financing and investment decisions of firms.

There are several important reasons for studying the taxation of corporate capital gains. First, while many of the economic issues regarding the tax effects of corporate and individual capital gains are similar, the possible distortions in the corporate and individual settings differ along some dimensions. For example, taxing corporate capital gains can impede asset sales and reorganizations that reallocate capital between firms. If such reallocations raise the productivity of assets, then discouraging these transactions reduces the pretax rate of return. In contrast, for most assets held by individuals, the identity of the owner is unlikely to affect asset returns. ${ }^{1}$

\footnotetext{
${ }^{1}$ Edwards, Lang, Maydew, and Shackelford (2003) consider the effect of such potential reallocations by examining the stock market reaction to the German tax reform of 2000 that eliminated the capital gains tax on corporate crossholdings. Given Germany's history of substantial corporate crossholdings, the reform was predicted to have
} 
More generally, the increased emphasis on the role of corporate governance in determining economic performance suggests that tax policy that alters the incentives for cross-holding or corporate venture capital can have important economic consequences. ${ }^{2}$ Finally, if firms are deterred from disposing of assets as a result of the capital gains tax, corporate capital gains taxes potentially exacerbate preexisting distortions arising from capital market imperfections that make external finance more costly.

Second, President Bush's recent proposal to eliminate the double taxation of corporate income brought to the forefront the question of the appropriate structure of capital income taxation. With regards to corporate investment in other corporations, U.S. tax policy provides corporations some relief from multiple layers of taxation on intercorporate dividends through the Dividends Received Deduction (DRD), which allows the exclusion of the majority of intercorporate dividends from the corporate income tax. The logic behind the DRD is to avoid having a full third layer of taxation on capital income to the U.S. tax system that already taxes corporate income twice (i.e., corporate income is taxed at the corporate level and the dividends are taxed at the shareholder level). By this logic, one might expect that capital gains earned on intercorporate investments would similarly be provided some relief but the tax code does not provide a preferential corporate tax rate for capital gains. Understanding how corporate capital gains taxes influence the holding behavior of firms provides a first step in understanding the consequences of this policy as an element in the overall system of capital taxation.

Third, the volume of corporate capital gains is substantial, and increasingly so, when compared with either individual capital gains or other metrics of corporate activity. From 1954 1999, corporations reported realized net long term capital gains that averaged 30 percent of the realizations reported by individuals. By 1999, corporate net long term gains were more than 20 percent of corporate income subject to tax and averaged 16 percent through the 1990s. From a tax policy perspective, given that corporations face a tax rate of up to 35 percent on realized net

sweeping effects in the level of merger and acquisition activity in Germany; Edwards et al. find a substantial stock market impact of the reform but it is concentrated among a small number of banks and insurance companies with substantial cross-holdings. They report that the early evidence on the amount of corporate restructuring after the tax reform does not support the idea of widespread restructuring; however, the implementation of the tax reform corresponded to a worldwide slowdown in merger activity so it is difficult to measure the tax effect.

${ }^{2}$ See Morck (2003) on the interaction of cross-holdings and intercompany dividend tax policy, Wolfenzon (1999) on the consequences of pyramidal ownership and Gompers, Lerner and Scharfstein (2003) on corporate venture capital activity. 
capital gains while individuals face a maximum tax rate of 15 percent on capital gains, the taxation of corporate capital gains has substantial revenue consequences.

We examine several aspects of corporate capital gains taxation. The incentives for realization are fairly complex and we begin with a discussion of tax policy with particular reference to the effects of taxes on net long-term gains. With the incentives and potential economic effects established, we outline the scope of this activity and distinguish between the types of capital gains realized and characterize their distribution relative to several benchmarks. We employ two empirical approaches to examine the responsiveness of corporate capital gains to variation in marginal tax rates. Following Plesko (2002), we study the time series behavior of aggregate corporate capital gains realizations. In this analysis, as in the studies of individual capital gains taxes (see Auerbach (1988) and Eichner and Sinai (2000)), we rely on time series variation in tax policy to identify possible tax effect on realizations. We add a number of additional controls for possible determinants of corporate capital gains - including proxies for sentiment, consolidation activity, and capital market activity - and find statistically significant elasticities of approximately -1.3 for corporations with respect to realization behavior.

Such a time-series analysis is problematic for several reasons so we turn to firm-level financial reporting data to examine whether the propensity to sell assets or realize gains is related to firm-specific variation in estimated marginal tax rates. For the firm-level analysis, the key variation in effective tax rates arises due to the rules related to operating losses. Using proxies for the marginal tax rate provided via the methodology in Graham (1996) and controlling for firm characteristics and time-varying investment opportunities, we find that the sales of investments and property, plant, and equipment (PPE) are more likely and considerably larger in low-tax years. In addition to this evidence on disposal behavior, the likelihood and volume of gains is particularly guided by tax considerations.

In the next section, we review the basic tax rules governing corporate capital gains. In section 3, we discuss the various incentive effects of corporate capital gains taxation, including both the efficiency costs to such taxes and how these taxes affect corporate tax planning efforts. In section 4, we provide an overview of general features of corporate capital gains realizations and broad time series trends in corporate capital gains realizations. Section 5 provides the results of our time series analysis of corporate capital gains realizations. Section 6 presents analysis that 
examines firm-level variation in realization behavior. In section 7, we conclude with directions for further research.

\section{U.S. Taxation of Corporate Capital Gains}

In determining the tax burden on corporate capital gains, three elements are critical - the definition of capital gains income for corporations, the applicable tax rate on corporate capital gains income and the rules for netting capital gains with other sources of income including how capital gains and losses interact with loss carryforward rules. In this section, we address each of these elements in turn and then frame these elements in historical and international perspective. ${ }^{3}$

\subsection{Definition of Capital Gain}

Capital gains or losses arise from the sale of capital assets. Capital assets are defined as all assets except: (1) inventory; (2) accounts or notes receivable through the ordinary course of business; (3) real or depreciable property used in a business; (4) copyright, literary, musical, or artistic composition held by the creator; and (5) certain publications of the U.S. government. ${ }^{4}$ The major categories of capital assets include: (1) investment assets, such as stocks and bonds; (2) assets (including land) held for long-term investment rather than commercial purposes; (3) self-created patents (see IRC section 1235); and (4) goodwill and going-concern value created by a firm.

In addition to the sale of capital assets, capital gains can arise from the sale of real or depreciable property (so-called section 1231 assets) under some circumstances. If these assets are sold for a loss (e.g., the sales price is less than the basis after adjusting for depreciation), then the loss is considered ordinary in character. If such assets are sold for a gain relative to the adjusted basis, then the character of the income depends on the recapture rules. To the extent that the gain arises from deductions for previous depreciation, the gain is considered ordinary income; however, for gains in excess of the amount of previous depreciation, the gain is considered capital in character. The logic behind the recapture rules that classify gains

\footnotetext{
${ }^{3}$ Our discussion of the tax rules for corporate capital gains focuses on the regular corporate income tax without considering the effects of the Alternative Minimum Tax (AMT). In general, under current tax rules, capital gains realizations do not generate preference items for the AMT. However, for the sale of depreciable assets, the AMT uses slower depreciation schedules which tend to result in smaller gains (or larger losses) from the sale of such assets. This difference in depreciation schedules tends to reduce the tentative AMT tax liability for a corporation that sells depreciable assets.

${ }^{4}$ Section 1221 of the Internal Revenue Code.
} 
associated with previous depreciation as ordinary income is that the firm has previously deducted the depreciation allowance from ordinary income but selling the asset for more than its adjusted basis suggests that the depreciation allowances were faster than the asset actually depreciated. ${ }^{5}$

A critical element of the definition of a capital gain is that it depends on an observable transaction, typically the sale of an asset. The realization-based nature of capital gains taxation creates numerous tax planning incentives, as discussed below. It also complicates measuring the annual effective tax rate on capital gains since the holding period influences the present value of the tax liability associated with owning the asset. When statutory tax rates do not increase over time, the ability to defer the realization of gains reduces the tax burden on the investment.

\subsection{Tax Rates on Corporate Capital Gains}

Unlike individuals who face lower tax rates on capital gains income than on ordinary income, U.S. corporations do not receive preferential tax rates on realized capital gains. Net realized capital gains are added to ordinary income in computing the firm's taxable income. ${ }^{6}$ Given that corporations do not receive a preferential tax rate on capital gains income relative to ordinary income, the distinction between capital income and ordinary income is often not critical for a firm's tax liability. However, as discussed below, the character of income affects which types of income can be netted against other types of income and the rules for how firms with net losses can use losses to offset previous or future income.

\subsection{Combining Capital Gains, Losses, and Ordinary Income}

Much of the complexity of taxing corporate capital gains arises from the rules associated with matching different types of capital gains and losses (e.g., short-term versus long-term), pooling different types of income, and carrying losses forward and backward. The general rule is that ordinary income and losses, capital gains and losses, and gains or losses on section 1231 assets are aggregated separately. Within capital gains, taxpayers separately aggregate short-term (defined as having a holding period of less than one year) capital gains and losses and long-term

\footnotetext{
${ }^{5}$ The recapture rules are especially important when depreciation allowances for tax purposes are accelerated relative to economic depreciation and when capital gains income faces a lower tax rate than ordinary income. Both of these conditions held before 1986 and created incentives for firms to "churn" assets by depreciating new assets and then selling them for a gain. For an analysis of these incentives and the role of the recapture rules, see Gordon, Hines, and Summers (1987).

${ }^{6}$ Technically, for historical reasons, corporations have the option of adding capital gains to ordinary income or facing an alternative tax rate of 35 percent, which is the same as the current top corporate marginal tax rate.
} 
capital gains and losses (including any capital gains from the disposition of section 1231 assets). If one of the holding period baskets results in a net gain and the other holding period basket results in a net loss, then the net loss in one basket can be used to offset the net gain in the other basket.

After completing this two-step netting process, a net capital gain is included in taxable income; however, corporations are not allowed to use a net capital loss to offset ordinary income. ${ }^{7}$ Instead, corporations with net capital losses must apply the carryback and carryforward rules. Current law allows capital losses to be carried back to offset net capital gains in the previous three years or carried forward to offset net capital gains in the subsequent five years. ${ }^{8}$ Since the tax law does not allow for an interest calculation to compensate for the time value of money, carrying losses forward is less valuable than an immediate tax refund or deduction against ordinary income (assuming that the firm’s statutory tax rate is constant over time).

In general, the netting rules give corporations a preference for capital gains income over ordinary income but ordinary losses over capital losses. Capital gains have an advantage over ordinary income in their ability to offset capital losses. In contrast, ordinary losses are preferable to capital losses since they can offset ordinary income or capital gains income while capital losses can only offset capital gains via the netting rules for capital gains.

\subsection{Tax Policy towards Corporate Capital Gains over Time}

Tax rules governing corporate capital gains have changed over time in a variety of ways. One major change over time is whether corporate capital gains face a preferential rate relative to ordinary income. Before the Tax Reform Act of 1986, corporations could base their tax liability on having net capital gains (i.e., net long-term capital gains in excess of net short-term losses) taxed at an alternative tax rate. The corporation would pay the minimum of its tax liability including net capital gains as ordinary income and using the alternative tax rate. In 1986, this alternative tax rate was 28 percent while the maximum tax rate on ordinary income was 46 percent. Between 1954 and 1986, the alternative tax rate varied between 25 and 30 percent.

\footnotetext{
${ }^{7}$ In contrast, individuals have a limited opportunity to offset ordinary income with capital losses.

${ }^{8}$ In contrast, individuals who exceed the annual limit on using capital losses to offset ordinary income have an unlimited number of years to carryfoward capital losses to offset future capital gains. In addition, the time limits on corporate carryovers for capital gains differ from those for operating losses. Operating losses can be carried back by two years or carried forward for twenty years.
} 
It is worth noting two things about the alternative tax rate system. First, since the same alternative rate applied to all firms, corporations with relatively low income might prefer the ordinary income tax rate over the alternative tax rate due to the graduated corporate tax rate schedule. Second, since the definition of net capital gains uses the distinction between long- and short-term capital gains, the holding period distinction was more important before 1986 than after 1986 with corporations preferring to realize long-term capital gains rather than short-term capital gains, in order to qualify for the lower alternative tax rate. ${ }^{9}$

\subsection{An International Perspective on the Taxation of Corporate Capital Gains}

The taxation of capital gains for both individuals and corporations varies substantially across countries. Policies can differ along several dimensions. First, how are capital gains taxed relative to other forms of income? Second, do the tax rules for corporate capital gains differ from the tax rules for the capital gains of individuals? One difference is whether capital gains are taxed at a different tax rate, including the possibility of exemption or exclusion from taxation, than ordinary income. This rate differential can be targeted toward specific types of assets (e.g., shares in publicly-traded firms) or require specific holding periods (e.g., a lower tax rate on long-term capital gains than on short-term capital gains). Indexing of cost basis is another policy option, though somewhat rare. Some countries allow for exemptions for individuals of some threshold amount of gains in each year (e.g., in 1998, France allowed \$8,315 of gains to be excluded from personal income taxation); ${ }^{10}$ however, these policies do not typically extend to corporate shareholders. In addition, countries could allow for rollover provisions in which gains continue to be deferred provided that the proceeds are invested in specific types of assets.

\footnotetext{
${ }^{9}$ As evidence that the holding period distinction affected behavior, consider the relationship between: (1) the difference between the top ordinary income tax rate and the long-term capital gains tax rate and (2) the ratio of net short-term gains to net long-term gains (taken from the Corporate Statistics of Income data described below). From 1954 to 1986, the difference between the ordinary income tax rate and the capital gains tax rate for corporations ranged from 18 to 27.8 percentage points and the annual ratio of short-term to long-term gains averaged 0.057. From 1988 to 1998, there was no difference in the tax rates and the ratio of short-term to long-term gains was 0.20 . Thus, when it was more advantageous to recognize long-term capital gains instead of short-term gains (i.e., the earlier years), short-term gains were a much smaller percentage of total realizations than when firms were indifferent to the holding period.

${ }^{10}$ See American Council on Capital Formation (1998).
} 
The American Council on Capital Formation (1998) surveyed capital gains taxation across 24 countries for 1998. ${ }^{11}$ Of the 24 countries, six (Belgium, Denmark, Hong Kong, the Netherlands, Poland, and Singapore) exempted long-term (and, except for Denmark, short-term) capital gains income for both individuals and corporations. Three countries (China, Korea, and Taiwan) exempted gains associated with local companies or companies traded on the major stock exchange but taxed gains on other equities (and presumably gains associated with other assets). Another five countries (Canada, France, India, Indonesia, and Italy) had long-term capital gains tax rates below the top marginal income tax rate for both individuals and corporations. In eight countries (Argentina, Brazil, Germany, Japan, Mexico, Sweden, the United Kingdom, and the United States), individuals faced preferential tax rates (relative to ordinary income) for long-term capital gains but corporations could face the top marginal income tax rate on capital gains. ${ }^{12}$ In three of these countries (Argentina, Germany, and Mexico), individual shareholders were exempt from capital gains taxes. ${ }^{13}$ In two countries (Australia and Chile), capital gains were taxed at the ordinary income tax rates for both individuals and corporations; however, Australia allowed for indexing of cost basis for both individuals and corporations while Chile allowed corporations to index their cost basis and provided individuals an exemption for the first $\$ 6,600$ of capital gains.

Even this cursory review of capital gains taxes around the world reveals substantial heterogeneity in tax policies towards capital gains. The U.S. tax system of preferential capital gains tax rates for individuals but not for corporations is a relatively common approach but even more countries provide preferential tax rates for corporate capital gains income relative to ordinary income (either in the form of lower tax rates or exemption). The issue of the relative taxation of dividends and capital gains is also likely to differ across countries given the variation in the extent to which different countries have integrated their personal and corporate income tax systems. An open empirical question is whether this heterogeneity in tax policy affects asset

\footnotetext{
11 The survey, conducted by Arthur Anderson, focuses on the tax treatment of investment in equities. The countries included in the survey are: Argentina, Australia, Belgium, Brazil, Canada, Chile, China, Denmark, France, Germany, Hong Kong, India, Indonesia, Italy, Japan, Korea, Mexico, Netherlands, Poland, Singapore, Sweden, Taiwan, the United Kingdom, and the United States. Presumably, many countries have special tax rules pertaining to the gains or losses on specific assets.

${ }^{12}$ Among these countries, Japan and the U.K. are somewhat different than the others. In Japan, individual taxpayers have a choice between a 20.0 percent tax rate on the net gain (which is lower than the top marginal tax rate on ordinary income) or a tax of 1.25 percent on the sales price. In the U.K., individuals faced a sliding scale of tax rates such that the tax rate fell as the holding period increased; with a holding period of 10 years, an individual would only include 25 percent of the capital gain in the tax base. For corporations in the U.K. in 1998, the tax system allowed corporations to index their cost basis in calculating the gain.

${ }^{13}$ As discussed above, Germany subsequently eliminated the corporate capital gains tax on corporate cross-holdings.
} 
allocation and investment decisions and the level of the cross-ownership of corporate shares across countries.

\section{Corporate Capital Gains Taxes and Incentives}

The taxation of corporate capital gains affects incentives in three broad categories. First, it affects 'real' decisions that impact investment and financing decisions and the allocation of capital across firms and throughout the economy. Second, taxes can affect the timing of corporate decisions. Third, tax policy towards corporate capital gains can affect corporate tax planning activities. In this section, we discuss each of these types of possible behavioral responses.

\subsection{The Allocation of Capital and Corporate Capital Gains Taxes}

The allocative effects of capital gains taxation have primarily been discussed in the context of individual investors and it is useful to anchor a discussion of the allocative effects for corporations in this literature. For individuals, capital gains taxes can affect investment decisions in two ways. First, in deciding among assets in which to invest, holding the statutory tax rate constant, the effective tax rate on an asset that is taxed upon realization is lower than the effective tax rate on an asset whose return is taxed annually. ${ }^{14}$ Thus, assets with returns that are taxed upon realization are tax advantaged relative to assets that face annual taxation. In addition to affecting capital allocation by pushing more capital into assets that produce capital gains, this differential taxation can also affect asset prices and future returns. In response to their favorable tax treatment, assets that yield capital gains may offer lower pretax rates of return (after adjusting for risk), which might offset the tax advantages of capital gains generating investments.

Second, once investors have an appreciated position, realization-based taxation provides an incentive for investors to defer their tax liability by delaying the sale of their assets. This incentive to delay realization is known as the 'lock-in' effect, which is commonly analyzed in the context of individuals who own a portfolio of financial assets. ${ }^{15}$ By deferring realization, investors effectively receive an interest-free loan in the amount that they would pay in taxes if

\footnotetext{
${ }^{14}$ We focus on the effects of realization-based taxation. In addition, policymakers frequently debate whether capital gains should be taxed at a lower tax rate than other types of income, under the common assertion that a lower tax rate on risky investment will promote risk taking. Despite the common claim that lower tax rates on capital gains promote risk-taking, the theoretical relationship between the tax rate and the amount of risk-taking is ambiguous since the tax rate affects both the expected return and the variability of returns.

${ }^{15}$ For recent analyses of the lock-in effect, see Klein (1999, 2001), Dammon, Spatt and Zhang (2001).
} 
they sold the asset and paid taxes. The lock-in effect distorts investors' portfolio choices because it creates a friction for reallocating capital across investments. Investors may retain an appreciated position even when another investment would provide a superior expected return after controlling for the riskiness of the position.

In contrast, if an asset falls in value, then investors may have an incentive to accelerate selling the asset in order to benefit from deducting the loss against other income (when allowed). Thus, realization-based taxation provides incentives for selective realizations by which investors typically minimize taxes by selling their losers and holding their winners. In the extreme, these optimal trading strategies create opportunities to eliminate income taxation (see Stiglitz, 1983); however, the combination of transaction costs and tax restrictions (e.g., loss limitation rules) prevent these strategies from abusing the capital gains tax rules to the point of eliminating overall income taxation.

Poterba (2002) reviews the efficiency consequences of capital gains taxation on individuals. One of the challenges for modeling the deadweight loss of capital gains taxation is that a complete model requires understanding investors' trading behavior in the absence of taxation. Trading behavior depends, in part, on heterogeneous beliefs about future returns that have proven to be a difficult feature to include in a model with taxation. Part of the deadweight loss arises because individuals hold suboptimal portfolios, in terms of riskiness or in terms of expectations about future returns. This distortion is greater if individuals' risk preferences change with age or if the risk characteristics of an investment change over time. Also, the distortion is probably smaller when investors' have relatively similar beliefs about future returns or have the ability to undertake investment trading strategies that allow investors to reap the benefits of a sale (e.g., liquidity and disposition of risk) without triggering a capital gain.

For evaluating the efficiency costs of corporate capital gains taxation, some of the issues that are pertinent for analyzing individuals are less important for corporations. For example, lifecycle concerns over saving and portfolio choice are not critical issues for corporations. Likewise, concerns over a mismatch between risk preferences and the riskiness of a portfolio of assets are less likely to be concerns for corporate investors since the individuals who own the corporation can diversify such risk issues. 
However, the distortions from capital gains taxes may have effects on corporations that are less relevant for individuals. Corporate investment often differs from the types of investments made by individuals. For individuals, the identity of who owns an asset rarely affects the asset's rate of return, at least for the 'portfolio' investments often considered in discussing the lock-in effect. While this may be true for the liquid investments of corporations, who owns corporate assets often affects the return on the assets. These returns generated from matching specific assets with specific owners add another dimension to the deadweight loss from capital gains taxation. For example, consider a corporation that is considering selling a division to another firm. If the incumbent owner has an unrealized capital gain on the division, then the capital gains tax might impede the transaction, even when the potential acquirer has a relatively high rate of return from owning the division. When the realization-based capital gains tax discourages transactions, the social cost is the difference in the returns that could be owned by the two different owners.

In addition to the possibility of mismatching in the asset market, the patterns of corporate cross-holdings, and the accompanying governance issues associated with those cross-holdings, could be influenced by corporate capital gains taxation. La Porta et al. (1998) document the wide variety of corporate cross ownership around the world and the prevalence of pyramidal ownership, to which the U.S. experience is a notable exception. Morck (2003) suggests that tax rules on intercorporate dividends (for which, as Morck shows, the U.S. is exceptional compared to other countries in levying an income tax) and corporate dividends to shareholders interact in the U.S. in a manner that prevents pyramidal ownership and the associated potential governance abuses. Presumably, the tax on corporate capital gains is an even more important deterrent to cross-holdings given the DRD. ${ }^{16}$ In addition to these effects on the patterns of ownership, corporate capital gains taxes may shape corporate venture capital activity and the overall venture capital environment given the interactions between corporate venture capital and venture capital more generally. ${ }^{17}$

\footnotetext{
${ }^{16}$ Paul (2003) argues that the triple taxation imbedded in corporate capital gains taxation has grown more important recently as U.S. corporations have entered into more relationships that involve intercorporate equity holdings. In addition, she discusses how the repeal of the General Utilities doctrine as part of the Tax Reform Act of 1986 has increased the importance of corporate capital gains taxation.

${ }^{17}$ See Gompers and Lerner (2002) and Gompers, Lerner and Scharfstein (2003).
} 
Finally, capital market imperfections may exacerbate the efficiency costs of the taxation of corporate capital gains taxation. Without capital market imperfections, corporations could finance new projects by attracting new investors; with capital market imperfections, asset sales can be a source of financing for new projects. The possibility of selling existing assets to finance new projects has received relatively little attention in the corporate finance literature. As elaborated below, corporate capital gain realizations constitute a significant fraction of corporate cash flow. As a transaction-based tax, the capital gains tax extracts a toll from firms that want to sell one set of assets to invest in another set of assets.

Overall, the magnitude of the economic distortions caused by capital gains taxation depends upon the elasticity of behavior along the various relevant margins. For individuals, understanding the elasticity of capital gains realizations to the tax rate is a starting point for measuring the efficiency cost; however, the realizations elasticity does not measure the extent to which the capital gains tax distorts portfolio composition. For corporations, the efficiency cost depends on the heterogeneity in asset returns across different owners and the extent to which the capital gains tax reduces capital reallocation across firms. However, measuring the elasticity of realizations with respect to the tax rate may only capture a small part of the efficiency cost of corporate capital gains taxation.

\subsection{Fluctuations in Tax Rates and Timing Incentives for Corporate Capital Gains}

In addition to the relationship between the levels of realization and tax rates, when tax rates change over time, either due to legislated changes in the tax code or due to changes in firmspecific characteristics, firms have an incentive to time their realizations of capital gains and capital losses. The simple adage is to realize losses when the marginal tax rate is high and to realize gains when the tax rate is low. If firms anticipate changes in future tax rates, then anticipated tax rate increases can induce firms to sell assets with appreciated values and to defer the sale of assets with unrealized capital losses.

A standard issue in the debate over the realizations elasticity of individual capital gains is separating the responsiveness of realizations into the responsiveness to 'permanent' changes in tax rates versus 'transitory' changes in tax rates. ${ }^{18}$ A response to transitory changes in tax rates is more like to involve a pure shift in the timing of asset sales rather than an increase in the long-

\footnotetext{
${ }^{18}$ See Burman and Randolph (1994).
} 
run amount of realizations. This same issue arises in considering corporate capital gains. Changes in tax policy can lead to anticipated changes in tax rates that affect behavior.

Given the graduated corporate tax rate system and the loss carryforward regime, variability in corporate profitability can generate firm-specific variation in effective marginal tax rates. For example, a firm with net operating loss carryforwards can recognize capital gains without paying taxes in the current year. Instead, the realized gain will offset part of the net operating loss carryforward and reduce the stock of carryforwards taken into the future. Effectively, the realized capital gain will most likely increase the firm's future tax liability when it returns to paying taxes.

\subsection{Tax Planning and Corporate Capital Gains Taxes}

The taxation of capital gains also affects the tax planning efforts of U.S. corporations. In general, these tax planning responses lead to financial consequences without greatly changing the real activity of the firm. A general rule for corporate tax planning is that firms prefer to have capital gains income but ordinary losses since capital gains can be used to offset either capital losses or ordinary losses.

We now turn to several examples of corporate tax planning that are affected by realization-based taxation of gains, especially capital gains. Our first example is how the realization-based nature of capital gains taxation affects the design of merger and acquisition transactions. We discussed above that capital gains taxes could inhibit some asset sales. In addition, the tax rules influence the form of asset transfers. In some cases, it is possible to structure an acquisition in a way to defer the realization of capital gains taxes; a common feature in deferring the capital gains tax is that the 'seller' accepts stock from the acquirer instead of cash. $^{19}$ For example, instead of selling a division for cash and realizing a gain, a corporation can exchange its equity in the division for stock of the acquirer and defer the realization of the gain.

Early empirical research on the effects of taxes on merger and acquisition activity found a limited role for taxes. Auerbach and Reishus (1988) find that only a minority of mergers from 1968 to 1983 had large enough tax benefits that the taxes may have been a motivating factor in

\footnotetext{
${ }^{19}$ See Scholes, Wolfson, Erickson, Maydew, and Shevlin (2002) for an overview of how capital gains taxes affect mergers and acquisitions.
} 
the reorganization; ${ }^{20}$ furthermore, they find little evidence of taxes affecting the form of acquisitions but they recognize that their measures of tax benefits are imprecisely measured. In contrast, more recent research has documented a role for taxes in corporate reorganizations. For example, Maydew, Schipper, and Vincent (1999) examine a sample of divestitures in which the parent corporation plausibly could choose either an asset sale that would trigger the realization of gains or a 'tax-free' spin-off that would not trigger taxation. They find that the size of the tax differential between divestiture methods affects the form of divestiture; firms with the largest potential tax benefits from using a spin-off opt for spin-offs. ${ }^{21}$ Thus, realization-based taxation affects the form of the transaction. Moreover, the realization-based taxes on the sellers in a corporate reorganization can affect the price paid in the reorganization. Ayers, Lefanowicz, and Robinson (2003) report that the acquisition premium associated with taxable stock acquisitions increases with the capital gains taxes of the target shareholders (albeit their sample is based on individual rather than corporate shareholders). Erickson and Wang (2000) examine the acquisition prices when one corporation buys a subsidiary from another corporation and find that the price paid depends on the tax on the gain realized by the selling corporation.

A second tax planning example is that the realization-based nature of capital gains taxation provides an incentive for investors to seek alternatives to selling their investments. One possibility is to enter into a hedging transaction that can reduce the risk of the position and possibly raise cash. Such hedging transactions may be relevant when a corporation obtains shares in another corporation as payment in a corporate reorganization. ${ }^{22}$ Corporations can execute these hedging transactions through either private deals with investment banks or by issuing exchangeable securities. Gentry and Schizer (2003) examine a sample of corporations that issue public securities as a way of hedging an appreciated position, raising cash, and deferring capital gains taxation. While the volume of public transactions has been relatively modest (roughly \$25 billion between 1993 and 2001), private transactions may actually have

\footnotetext{
${ }^{20}$ Auerbach and Reishus focused on elements of the tax code that potentially made mergers more attractive, such as allowing firms to use tax losses and credits (rather than carry them forward), a step-up in asset basis, and increased interest deductions; Franks, Harris, and Mayer (1988) also conclude that taxes do not seem to affect the form of the transaction for mergers.

${ }^{21}$ In general, Maydew et al. report that the potential non-tax benefits of taxable transactions (e.g., raising capital from assets sales may be a relatively inexpensive source of funds) lead many firms to use taxable asset sales and forego the tax benefits of a spin-off.

${ }^{22}$ For example, in 1996, Kerr-McGee acquired stock of Devon Energy in exchange for some oil fields and in 1999 Kerr-McGee issued securities that hedged some of the risk of holding Devon Energy stock (see Gentry and Schizer, 2003, for more examples of such transactions).
} 
lower transaction costs and, hence, may be the predominant form of hedging. Again, the government designs tax rules to make this sort of tax planning difficult, such as rules that treat the transaction as a sale if the issuer has eliminated all of the risk of the position. Nonetheless, corporate capital gains taxation plays an important role in securities market innovations aimed at allowing firms to avoid the realization-based tax.

A third example of tax planning incentives arises from the differential taxation of corporate capital gains income and intercorporate dividend income. As mentioned in the introduction, the dividends received deduction (DRD) for intercorporate dividends provides some relief from the potential 'triple' taxation of corporate income when corporations own shares in other corporations. The DRD typically reduces the tax rate on intercorporate dividends by 70 percent, so that a corporation facing a 35 percent tax rate on ordinary income faces a 10.5 percent tax rate on dividend income; however, capital losses are deductible against capital gains so that the tax rate on capital losses may still be 35 percent. The DRD makes corporations a natural clientele to invest in high-dividend yield stocks, such as preferred stock. ${ }^{23}$ In addition, these clientele effects can affect when a corporation sells stock. For a corporation considering selling shares near the ex-dividend day, the DRD provides an incentive for the corporation to delay the sale until after the ex-dividend day since this delay will increase the dividend portion of the return and increase the after-tax return.

At the extreme, these clientele effects give corporations an incentive to engage in shortterm trading strategies known as dividend capture or dividend stripping. Dividend stripping is an investment strategy aimed at earning dividend income even if the dividend income is offset by an equal amount of capital losses. Suppose a corporation could invest in a high-yield stock just before its ex-dividend day and that on the ex-dividend day the stock price will drop one-for-one with the amount of the dividend. A short-term position in this stock might yield $\$ 100,000$ of dividend income but would also result in $\$ 100,000$ in capital losses so that the economic income on the position is zero. However, the dividend income might result in a tax liability of $\$ 10,500$ while the capital loss (assuming that it can be used to offset capital gains) creates a tax benefit of $\$ 35,000$. Thus, the tax rate differential creates a net benefit of $\$ 24,500$. Given the size of this potential tax arbitrage, it is not surprising that the tax code includes a variety of restrictions

\footnotetext{
${ }^{23}$ For evidence consistent with the formation of investor clienteles for dividends, see Dhaliwal, Erickson, and Trezevant (1999).
} 
aimed at limiting this type of strategy, primarily minimum holding period requirements to qualify for the DRD.

Evidence on the importance of dividend stripping is scarce. The most direct evidence is from Koski and Scruggs' (1998) examination of NYSE trading audit data from the early 1990s, which has the buying and selling volume of different types of traders. Consistent with corporate dividend capture, they find increased trading volume for corporations just before the ex-dividend day; however, the strength of the result is tempered by this increase in volume being uncorrelated with the dividend yield, whereas one would expect a positive correlation since the profitability of dividend stripping increases with dividend yield. In addition, Naranjo, Nimalendran, and Ryngaert (2000) examine the ex-dividend stock returns of high yield stocks. They find that after May 1975, when brokered commissions were introduced on the New York Stock Exchange, the ex-dividend day returns for these stocks were negative (i.e., on the ex-dividend day, share prices fall by more than one-for-one with the dividend) in every year except 1994, which is consistent with corporate dividend capture affecting the stock returns due to corporations bidding up the price of the shares before the ex-dividend day. Furthermore, these negative returns are correlated with the corporate tax differential on dividend and capital gains income, consistent with the tax differential driving trading behavior. Grammatikos (1989) focuses on the 1984 tax changes that increased the holding period required to qualify for the DRD, which presumably increased the cost of dividend stripping by increasing the associated risk. Consistent with the increased holding period reducing dividend stripping, he reports that abnormal returns on the ex-dividend day increased after the tax change. Overall, these studies suggest that corporations engage in some amount of dividend capture trading but that both transaction costs associated with trading and tax restrictions play important roles in limiting this behavior.

\section{The Scope of Corporate Capital Gains}

Before turning to the effects of corporate capital gains taxes on the realization behavior of firms, it is useful to get a sense of the magnitude and distribution of corporate capital gains. Data on corporate capital gains is available from 1954 to 1999 through the Statistics of Income (SOI) reports on corporation income tax returns. The top panel of Table 1 provides summary numbers on the aggregate amount of gains for 1999 distinguished by type of gain. In 1999, net long term capital gains realized by all corporate entities were $\$ 146.5$ billion, net short term capital gains 
realized were $\$ 94.9$ billion and net gains on all noncapital assets were $\$ 64.7$ billion. Given the proliferation of pass-through corporate entities and the possible concentration of capital gains in particular sectors, it is useful to isolate the volume of gains according to these distinctions. While net long term capital gains and net gains on noncapital assets are largely in non-pass through entities, the vast majority of net short term capital gains in 1999 were in pass-through entities which were largely in the Finance, Insurance and Real Estate (FIRE) sector.

In order to further isolate the sectoral distribution of gains and to ensure that they do not reflect a peculiarity associated with 1999, the bottom two panels of Table 1 provide the share of overall economic activity and of gain activity through the 1990s for manufacturing, FIRE and other industries for all entities and for only non-pass through entities. Throughout the 1990's, net short term gains were concentrated in FIRE. In contrast, net long term gains were distributed across all three industrial groupings in a manner that accords with the underlying distribution of assets across those groupings. Finally, net gains on noncapital assets are disproportionately in manufacturing and other industries (relative to their shares of total assets) suggesting that these gains correspond to the section 1231 assets described above. Given the distribution of gain activity across sectors and types, the analysis and descriptive statistics that follow emphasize net long term gains from the SOI data.

The data in Table 1 distinguish short-term and long-term gains and separate the gains on noncapital assets but do not address what specific types of assets are being sold. While such a breakdown is not readily available for the U.S., Inland Revenue reports what types of assets underlie corporate capital gains realizations for the U.K. ${ }^{24}$ For the accounting period ending 2000-01, 51 percent of the gains of non-life insurance companies were from financial assets; more specifically, 16 percent were from shares listed on the London exchange, 16 percent from unquoted shares, 17 percent from selling subsidiaries, and 2 percent from other financial assets. The remaining 49 percent of capital gains were from nonfinancial assets that were concentrated in intangible assets (27 percent of total gains) and commercial assets (13 percent of total gains). In terms of holding periods, for gains realized in 2000-01, 70 percent of the gains on financial assets and 58 percent of the gains on nonfinancial assets were on assets held for over 10 years

\footnotetext{
${ }^{24}$ Source: Inland Revenue, National Statistics, http://www.inlandrevenue.gov.uk/stats/capital_gains/menu.htm. It is worth noting that Inland Revenue states that annual data varies substantially across years.
} 
which highlights the importance of tax deferral for gains taxation. ${ }^{25}$ To the extent that U.S. and U.K. corporations are similar, these data provide a general picture of the types of assets that generate corporate capital gains in the U.S.

Given the familiarity with capital gains realized by individuals, it is useful to frame the volume of net long term corporate capital gains realizations relative to those gains. As Figure 1 demonstrates, the ratio of realized corporate capital gains to realized individual capital gains has averaged approximately .30 from 1954 to 1998. It is useful to note that this ratio has evolved significantly over that period. Until the late 1970's, this ratio was both relatively lower and more consistent than the period after the late 1970s. Specifically, from 1980 on, this ratio averaged 0.36 and ranged from a high of .45 in 1987 to a low of 0.28 in 1984. Overall, the relative magnitude of corporate and individual capital gains suggests further research on corporate capital gains is warranted, especially since corporations face higher tax rates on capital gains than individuals face.

To give a sense of how important capital gains are for corporate behavior, it useful to frame the magnitude and trends in corporate capital gains realizations relative to corporate cash flow and assets. In order to do that, Table 2 provides the ratios of net long term capital gains realizations to income subject to tax and assets and of all gains to assets for the 1990s by industrial grouping. Of course, the gain may be much smaller than the proceeds raised by selling an asset so that merely measuring gains understates the importance of asset sales for cash flow. ${ }^{26}$ This ratio may be subject to cyclical effects since it was its highest value (33.5 percent) during the one economic downturn during this period (1990). In general, for all industries, there seems to be an upward trend in the second half of the sample with the ratio of net long term capital gains to income subject to tax increasing from 9.6 percent in 1994 to 20.9 percent in 1999. This same ratio for the basic industrial grouping of manufacturing, FIRE and all other industries suggests that FIRE is particularly reliant on net long term capital gains but that the cyclicality and recent increase is evident for manufacturing and other industries as well. By 1999, 13.2 percent of income subject to tax for manufacturing firms was net long term gains.

\footnotetext{
25 The pattern of holding periods varies over time (even more than the variation in the sources of gains); for 19992000, 37 percent of realized gains on financial assets and 54 percent of gains on nonfinancial assets were from assets held over 10 years.

${ }^{26}$ If corporations more readily sell assets with loses than those with gains (a pattern encouraged by the tax rules), then the net gain may be a very small fraction of the cash proceeds from aggregate sales.
} 
Given that the cyclicality and upward trend in this ratio may reflect the dynamics of income subject to tax rather than the dynamics of net long term capital gains, the second panel of Table 2 demonstrates that those same trends hold when scaling net long term gains by total assets. In 1999, firms across all industries realized net long term capital gains equal to 0.45 percent of total assets representing a sharp increase over the decade. The bottom panel of Table 2 aggregates all gains and compares them to total assets finding largely similar results. The upward trend in gains realizations appears to be particularly significant for the manufacturing sector.

\section{Evidence from Time-Series Analysis}

Analyses of capital gain realization behavior for individuals have employed the responsiveness of aggregate realizations to time series variation in tax rates. For example, Eichner and Sinai (2000) follow Auerbach (1988) in estimating long run elasticities on the basis of such a time series analysis. While limited in several ways, such an analysis of corporate capital gain realization is a useful starting point prior to turning to firm-level data.

Before turning to the time series regressions, it useful to get a sense of the general pattern in realization behavior and to compare it to the time series pattern of individual realization behavior. Figure 2 traces out the relationship between realization behavior at the individual and corporate level. Figure 2 plots the ratio of individual capital gains to household financial assets and the ratio of net long term corporate capital gains to total assets. Burman and Plesko (2002) provide a version of this figure but deflate the two nominal series and conclude that there exists a correlation of 0.97 over the period. Scaling realization amounts as in Figure 2 provides a similar conclusion regarding the high level of correlation between these series. Plesko (2002) interprets the high correlation between corporate and individual realization in the time series as evidence of some omitted variable in realization behavior that may bias estimated tax effects for individuals capital gains realization behavior. ${ }^{27}$

Our goal is to identify variables that may be omitted from the standard set of variables employed by Eichen and Sinai (2000) for individuals and by Plesko (2002) for both individuals and corporations. In searching for these omitted variables, we limit our analysis to corporate

\footnotetext{
${ }^{27}$ Plesko (2002) jointly estimates individual and corporate realizations and concludes that single-equation models of individual realization behavior overstate tax sensitivities for individual realization behavior.
} 
capital gains, which is the general focus of our paper, rather than estimating models for both individuals and corporations. Column 1 of Table 4 provides the baseline specification that follows Plesko's analysis of realization behavior for corporations, which in turn follows Eichner and Sinai and others in choosing explanatory variables. This specification employs the log value of aggregate corporate capital gain realization as a dependent variable and, in addition to the top corporate capital gains tax rate, controls for the price level (as measured by the GNP deflator), the value of corporate equities (as measured by the level of the S\&P 500), and GNP and the first difference of GNP. As with Auerbach (1988) and Eichner and Sinai (2000) all values are firstdifferenced to accommodate concerns regarding the presence of a unit root in these series.

The -9.20 coefficient on the corporate capital gains rate in column 1 translates into a tax elasticity of -2.6. Starting with this baseline set of variables, we consider other variables that might capture factors influencing realization behavior. Since these variables are only available after 1963, the specification in column 2 provides an alternative baseline specification for this shortened period with estimated coefficients on the corporate capital gains rate that are approximately the same as for the longer period examined in column 1.

Columns 3-6 consider several proxies for sentiment and capital market activity that could influence these series. Baker and Wurgler (2003) provide a review of various measures of sentiment and their interrelationship. If managers are able to opportunistically time sales and capitalize on market sentiment, these variables may explain realization activity. Similarly, if these realizations are related to trends in merger activity or equity offerings, then measured responsiveness to taxes could be mismeasured. Column 3 adds an additional control for the closed-end fund discount, which has been used to proxy for market sentiment. The coefficient on the capital gains rate moves modestly and retains its high level of significance while variation in the closed end fund discount appears to be associated with realization behavior to some limited degree. Column 4 tests for the role of merger activity by controlling for the share of value of the CRSP file that is acquired in a given year. ${ }^{28}$ Again, the coefficient on the capital gains tax rate is largely unchanged and remains significant while this proxy for merger activity does not appear to significantly determine realization behavior. Finally, the inclusion of the level of IPO activity in column 5 does appear to play a significant positive role in determining

\footnotetext{
${ }^{28}$ Andrade, Mitchell and Stafford (2001) provide background on the construction of this series.
} 
realization behavior and reduces the level and significance of the coefficient on the capital gains rate. Jointly controlling for merger and IPO activity as in column 6 produces a marginally significant coefficient that translates into a tax elasticity of -1.3 , which is at the upper-end of Eichner and Sinai's estimated elasticities for individuals.

Such a time series analysis provides indicative evidence that measures of capital market activity may shape realization behavior either because they provide an opportunity for corporations to disgorge capital gains or because they measure sentiment in a way that might shape realization behavior. Further investigation of the role of these measures of sentiment and capital market activity in determining individual and corporate realizations seems warranted. Inclusion of these measures of capital market activity still produces large, if only marginally statistically significant, tax elasticities for corporate realization behavior. Obviously, while this time series analysis has the advantage of capitalizing on significant variation in capital gains tax rates, it suffers from well-know econometric problems. In order to further investigate the effect of capital gains taxes on realization behavior, we turn to analysis of firm-level data.

\section{Evidence from corporate financial reports}

Much as Burman and Randolph (1994) and Auten and Clotfelter (1982) investigate individual realization behavior using micro data, this section employs firm-level data to investigate whether a firm's tax position influences the decision to dispose of assets and the nature of gain and loss recognition. We use financial reporting data from Standard \& Poor's Compustat industrial database to shed light on corporate capital gains behavior. Financial statements include several items related to taxable capital gains. First, firms report their proceeds from the sale of investments and their proceeds from the sale of property, plant, and equipment (PPE). Presumably, the sale of investments captures many assets defined by the tax code as ‘capital assets' and the sale of PPE captures so-called Section 1231 assets (which can create a combination of capital gain and ordinary income). For these variables, we use data from 1980 to 2002. Obviously, observing sales proceeds does not necessarily inform us about the recognition of gain or loss. For the years 1987 to 2002, Compustat reports the gain (or loss) on the sale of assets. This variable, however, may not perfectly match taxable capital gains (or losses) for several reasons. First, financial reporting does not isolate assets using the tax code’s definition of 'capital asset' so the financial reporting gain may include some ordinary income. 
Second, for depreciable assets, the depreciation rules differ between financial and tax accounting. Despite these measurement issues, we believe that financial reporting data can shed light on corporate capital gains behavior.

Unlike studies of individual capital gains realization behavior that use tax return data, financial reporting data has two distinct limitations. First, using such sources implicitly relies on the decision of a firm to disclose specific actions in public documents. Reporting decisions are mediated, presumably, by auditor advice and managerial motives. Having said that, it is unclear a priori why reporting the presence or volume of asset sales or gain/loss activity would be subject to anything but, possibly, materiality concerns. In addition, we should emphasize that financial accounting differs from tax accounting so the measured gain or loss from selling assets differs across accounting systems. Second, public financial documents do not allow one to infer precisely the tax position of a firm forcing us to rely on proxies devised by Graham (1996) that largely identify probabilities of having net operating losses. ${ }^{29}$

Before turning to our regression analysis of when firms sell assets and the associated gains or losses, the descriptive statistics in the bottom panel of Table 3 provide some useful information. To measure the propensity of different events, we create dummy variables for: whether a firm reports some proceeds from the sale of investments; (2) whether a firm reports some proceeds from the sale of PPE; (3) whether the firm reports a gain from the sale of assets; and (4) whether the firm reports a loss from the sale of assets. ${ }^{30}$ For the period from 1980 to 2002, 26 percent of firm-year observations contain positive values for the sale of investments and 50 percent report the sale of PPE indicating that asset disposal is fairly common. With regard to gains and losses, the sample is limited to the period from 1987 to 2002 but the implications are similar. Over this period, 45 percent of firm-year observations contain either a net gain or loss with 26 percent of those being gains and 19 percent of those being characterized as losses. As such, gain or loss recognition appears to be fairly common over the sample period.

The two panels of Table 5 analyze the determinants of disposal decisions by examining how taxes influence the decision to sell investments (in the top panel) and PPE (in the bottom

\footnotetext{
${ }^{29}$ We thank John Graham for making his tax rate variables available via his website at http://www.duke.edu/ jgraham/. A further discussion of the methodology underlying his tax rate measure is available in Graham (1996).

30 The dummy variables for recognizing a gain or a loss are created from a single continuous measure of the net gain from assets sales; hence, we cannot infer whether a firm simultaneously recognizes gains and losses.
} 
panel). The first three columns of each panel employ a dummy variable that is equal to one if there is a non-zero value for the sale of either investments (in Panel A) or PPE (in Panel B) as the dependent variable. We estimate linear probability models for the various extensive margins that we examine so that we can easily incorporate firm fixed effects in the econometric specification. The remaining three columns use the log of the value of those sales as the dependent variable. In examining the size of the sales, we only include observations that have the particular type of sale; hence, the regressions are conditional on having a sale and do not combine the effects of the explanatory variables on the extensive and intensive decisions regarding asset sales. As such, the latter three columns of both panels analyze whether taxes influence the magnitude of these sales conditional on the presence of a recorded sale. All specifications employ firm fixed effects and, as a consequence, are identifying tax effects from within-firm variation in a firm's tax status.

The first column of both panels employs only firm-level variation in tax rates as an explanatory variable and finds that firms time their disposal of investments and PPE to occur in years associated with low tax rates. The estimated coefficients imply that when a firm's effective marginal tax rate is ten percentage points higher, the probability of it selling investments decreases by 0.46 percentage points and the probability of it selling PPE decreases by 0.75 percentage points and both of these estimated effects are statistically different from zero at the 99 percent confidence level.

While firm fixed effects control for a host of unobservable characteristics, it is useful to also control for firm size and investment opportunities by include the natural logarithm of total assets and the natural logarithm of a proxy for a q-ratio. ${ }^{31}$ Since we add these control variables to the specification with firm fixed effects, the econometric identification for the size and investment opportunity variables arises from each firm's size and investment opportunities changing over time. The second column of each panel includes these additional control variables and finds that the tax effects identified previously remain statistically significant and are only diminished slightly. Turning to the estimated coefficients on the control variables, we find that when a firm is larger it is more likely to sell investments but less likely to sell PPE. When firms have better investment opportunities (i.e., higher values of q), they are less likely to sell PPE (and this estimated effect is statistically different from zero), which is not consistent with the

\footnotetext{
${ }^{31}$ This q-ratio is the ratio of total assets plus the difference between the market value and book value of equity to total assets.
} 
idea that firms sell assets as a source of financing when opportunities are good but outside sources of finance are limited. We do not find the relationship between investment opportunities and the sale of investments to be statistically different from zero.

By including firm fixed effects, our econometric identification strategy focuses on within firm variation over time. Some of this intertemporal variation arises from legislated changes in the tax schedule while some of the variation comes from changes in each firm's tax position for a given tax code (e.g., how it is affected by loss offset rules). In part, to separate these sources of variation, we include year fixed effects in the specification reported in the third column of each panel in Table 5. The inclusion of year fixed effects in the regressions has a quite small effect on estimated effects in the sale of investment regressions but the estimated effects in the sale of PPE regressions change considerably (e.g., the estimated coefficient on the marginal tax rate shifts from -0.0669 in the second column to -0.1223 in the third column). One possible explanation for this result is that the time series changes in the level of the corporate marginal tax rate are correlated with changes in depreciation rules (which are not as relevant for selling investments which typically are not depreciable assets). The year fixed effects may be capturing how changing depreciation rules affected the propensity to sell PPE and these differences may be correlated with the level of the tax rate.

The final three columns of each panel of Table 5 provide a similar analysis using the log value of proceeds from the sale of investments (in Panel A) and PPE (in Panel B) as the dependent variable. Conditional selling investments or PPE, a firm's tax rate is negatively related to the volume of its investment or PPE sales. These estimated effects are statistically different from zero at the 99 percent confidence level. Including controls for firm size and investment opportunities diminishes the magnitude of the estimated effect of the tax rate but it retains its high level of significance. While larger firms tend to sell a larger volume of investments and PPE (conditional on selling some assets), the estimated effect of investment opportunities (as measured by q) on the size of investment sales is positive (suggesting that firms with better investment opportunities sell more investment assets possibly as a source of financing investment in new projects) but the estimated effect of investment opportunities on the size of PPE sales is negative. Finally, the inclusion of year effects has little effect on the size or statistical significance of the estimated coefficients in the PPE regression; however, for the size of investment sales, the estimated effect of the marginal tax rate is much smaller and not 
statistically different from zero and the coefficients on the other explanatory variables also change dramatically.

The two panels of Table 6 provide a similar empirical framework to investigate the presence and magnitude of gains and losses on the sale of assets as reported by firms. In contrast to the two panels of Table 5, the two panels separately examine gain behavior (in Panel A) and loss behavior (in Panel B) but we cannot distinguish between investments and PPE. As noted above, 45 percent of all firm-year observations are associated with either a gain or loss with the majority of these non-zero observations being gains. Again, the latter three columns measure the effect of taxes on the size of gains and losses conditional on the existence of either gains or losses.

In Panel A of Table 6, the estimated effects of tax rates are broadly consistent with expectations. When a firm has a high marginal tax rate, it is less likely to report a gain from the sale of assets. The estimates imply that a 10 percentage point increase in the marginal tax rate decreases the propensity to realize a gain by between 0.397 to 0.757 percentage points and these estimated effects are statistically different from zero at the 95 percent confidence level. Furthermore, conditional on reporting a gain, the gains are smaller when the firm faces a higher marginal tax rate and this effect is statistically different from zero in the specifications with controls for firm size and investment opportunities. In addition, when a firm is larger, it is more likely to report gains and, conditional on having a gain, the gain is larger.

The behavior of reported losses, reported in Panel B of Table 6, is somewhat puzzling. Contrary to the prediction that firms with high tax rates will value reporting losses, the estimated coefficients on the marginal tax rate are negative for both the extensive margin of reporting a loss and the intensive margin of the size of the loss (conditional on having a loss). Two issues complicate the analysis of loss behavior. First, as mentioned above, much of the variation in Graham’s estimates of marginal tax rates is driven by the presence of operating losses. However, the firm's operating performance is not completely divorced from whether it has gains or losses on its existing investments. For example, poor operating performance may lead to both a low tax rate and a large stock of potential losses that the firm can recognize, which would be 
consistent with the estimated coefficients. ${ }^{32}$ Second, the netting rules for capital losses complicate the predicted relationship between tax rates and observed net losses. Suppose a firm has a high tax rate due to having substantial operating income. Since capital losses cannot be netted against positive operating income, it would not be surprising if we found no relationship between the observed tax rate and reporting a net loss. ${ }^{33}$

\section{Conclusions}

Corporate capital gain realizations are a significant component of corporate cash flow and increasingly so. Net long-term capital gains are significant compared to individual capital gains and are gaining in relative importance. As this paper outlines, the distortionary effects of such taxes largely subsume those associated with individual capital gains. Specifically, lock-in effects at the corporate level may alter productivity levels by changing the patterns of corporate and asset ownership in a manner that taxes on individual capital gains do not.

The time series analysis of this paper suggests that the elasticities of corporate realizations to tax costs is higher than those derived in similar equations used to estimate the elasticities of individual capital gains. Micro analysis further suggests that firms time their sales and magnitudes of investments and PPE opportunistically. Moreover, the micro analysis suggests that the realization of gains appears to be particularly shaped by tax incentives. In sum, the corporate capital gains tax regime appears to significantly influence the decisions of firms to dispose of assets and realize gains and losses.

Our empirical evidence captures only one dimension - realization behavior - of the effect of corporate capital gains taxes. More generally, these taxes are likely to influence business planning on a variety of margins - including merger activity, the initiation and termination of lines of business and the patterns of cross-holdings. In combination with the curious distinction between the treatment of intercorporate dividend payments and intercorporate capital gains, the results in this paper and these broader consequences suggest that tax policy for corporate capital gains may be ripe for reevaluation and that much more needs to be understood about how corporate capital gains taxes influence firm behavior.

\footnotetext{
${ }^{32}$ This endogeneity between firm performance and the effective marginal tax rate would bias against finding that high tax rates are associated with the lower propensity to recognize gains that we report in Panel A of Table 6.

${ }^{33}$ To sort through these issues, it would be helpful to have separate data on gains and losses so that one could observe how firms match capital losses with capital gains; unfortunately, we only have data on the net gain or loss.
} 


\section{References}

American Council on Capital Formation, 1998, An International Comparison of Capital Gains Tax Rates, August, Special Report, Washington DC: ACCF Center for Policy Research.

Andrade, Gregor, Mark Mitchell, and Erik Stafford, 2001, New Evidence and Perspectives on Mergers, Journal of Economic Perspectives (spring 2001): 103-120.

Auerbach, Alan. "Capital Gains Taxation in the United States: Realizations, Revenue, and Rhetoric.” Brookings Papers on Economic Activity No. 2 (1988): 595-631.

Auerbach, Alan J., and David Reishus, 1988, The Impact of Taxation on Mergers and Acquisitions. In Mergers and Acquisitions, ed. Alan J. Auerbach. Chicago: University of Chicago Press.

Auten, Gerald E. and Charles T. Clotfelter, 1982, Permanent versus Transitory Tax Effects and the Realization of Capital Gains, Quarterly Journal of Economics 97 issue 4, 613-632.

Ayers, Benjamin C., Craig E. Lefanowicz, and John R. Robinson, 2003, Shareholder Taxes in Acquisition Premiums: The Effect of Capital Gains Taxation, Journal of Finance, forthcoming.

Baker, Malcolm and Jeffrey Wurgler (2003), Investor Sentiment and the Cross-Section of Stock Returns, Working Paper, Harvard University.

Burman, Leonard E., and William C. Randolph, 1994, Measuring Permanent Responses to Capital-Gains Tax Changes in Panel Data, The American Economic Review 84 issue 4, 794809.

Burman, Leonard E. and George A. Plesko, 2002, Individual and Corporate Capital Gains Are Highly Interrelated, Tax Notes, October 28, 553.

Dhaliwal, Dan S., Merle Erickson, and Robert Trezevant, 1999, A Test of the Theory of Tax Clienteles for Dividend Policies, National Tax Journal 52 issue 2, 179-194.

Dammon, Robert M., Chester S. Spatt \& Harold H. Zhang, 2001, Optimal Consumption and Investment with Capital Gains Taxes, Review of Financial Studies 14 issue 3, 583-616.

Edwards, Courtney, Mark H. Lang, Edward L. Maydew, and Douglas A. Shackelford, 2003, Germany’s Repeal of the Corporate Capital Gains Tax: The Equity Market Response, Working Paper, University of North Carolina.

Eichner, Matthew, and Todd Sinai, 2000, Capital Gains Tax Realizations and Tax Rates: New Evidence from Time Series, National Tax Journal 53 issue 3 part 2, 663-682.

Erickson, Merle and Shiing-wu Wang, 2000, The Effect of Transaction Structure on Price: Evidence from Subsidiary Sales, Journal of Accounting and Economics 30, 59-97.

Franks, Julian R, Robert S. Harris, and Colin Mayer, 1988, Means of Payment in Takeovers: Results for the United Kingdom and the United States. In Corporate Takeovers, ed. Alan J. Auerbach. Chicago: University of Chicago Press. 
Gentry, William M., and David M. Schizer, 2003, Frictions and Tax-Motivated Hedging: An Empirical Exploration of Publicly-Traded Exchangeable Securities, National Tax Journal 56 issue 1, 167-195.

Gompers, Paul and Josh Lerner, 2002, "The Determinants of Corporate Venture Capital Success: Organizational Structure, Incentives and Complementarities,” in Morck, R. Concentrated Corporate Ownership (Chicago: University of Chicago Press).

Gompers, Paul, Josh Lerner, and David Scharfstein, 2003, Entreprenurial Spawning: Public Corporations and the Genesis of New Ventures, 1986-1999, NBER Working Paper No. 9816.

Gordon, Roger H., James R. Hines, Jr., and Lawrence H. Summers, 1987, Notes on the Tax Treatment of Structures. In The Effects of Taxation on Capital Accumulation, ed. Martin Feldstein. Chicago: University of Chicago Press.

Graham, John R., 1996, Proxies for the Corporate Marginal Tax Rate, Journal of Financial Economics 42, 187-221.

Grammatikos, Theoharry, 1989, Dividend Stripping, Risk Exposure, and the Effect of the 1984 Tax Reform Act on the Ex-Dividend Day Behavior, Journal of Business 62 issue 2, 157-173.

Klein, Peter, 2001, The Capital Gain Lock-In Effect and Long-Horizon Return Reversal, Journal of Financial Economics 59, 33-62.

Klein, Peter, 1999, The Capital Gain Lock-In Effect and Equilibrium Returns, Journal of Public Economics 71, 355-378.

Koski, Jennifer L. and John T. Scruggs, 1998, Who Trades Around the Ex-Dividend Day? Evidence from NYSE Audit File Data, Financial Management

La Porta, Rafael, Florencio Lopez-de-Silanes, and Andrei Shleifer, 1999, Corporate Ownership around the World, Journal of Finance 54: 471-517.

Maydew, Edward L., Katherine Schipper, and Linda Vincent, 1999, The Impact of Taxes on the Choice of Divestiture Method, Journal of Accounting and Economics 28, 117-150.

Morck, Randall, 2003, Why Some Double Taxation Might Make Sense: The Special Case of Inter-corporate Dividends, NBER Working Paper No. 9651.

Naranjo, Andy, M. Nimalendran, and Mike Ryngaert, 2000, Time Variation of Ex-Dividend Day Stock Returns and Corporate Dividend Capture: A Reexamination, Journal of Finance 55 issue 5, 2357-2372.

Paul, Deborah L., 2003, Triple Taxation, The Tax Lawyer, 56, 571-610.

Plesko, George A., 2002, Omitted Variable Bias In Time Series Estimates of Capital Gains Realizations, MIT working paper.

Poterba, James M., 2002, Taxation, Risk-Taking, and Household Portfolio Behavior, in A. Auerbach and M. Feldstein, eds., Handbook of Public Economics: Volume 3 (Amsterdam: North Holland, 2002), 1109-1171. 
Scholes, Myron S., Mark A. Wolfsosn, Merle Erickson, Edward L. Maydew, and Terry Shevlin, 2002, Taxes and Business Strategy: A Planning Approach. Prentice Hall, Upper Saddle River, NJ.

Stiglitz, J.E., 1983, Some Aspects of the Taxation of Capital Gains, Journal of Public Economics 21 issue 2, 257-94.

Wolfenzon, Daniel 1999, A Theory of Pyramidal Ownership, Harvard University Working Paper. 
Figure 1: Ratio of Corporate To Individual Capital Gains, 1954-1997

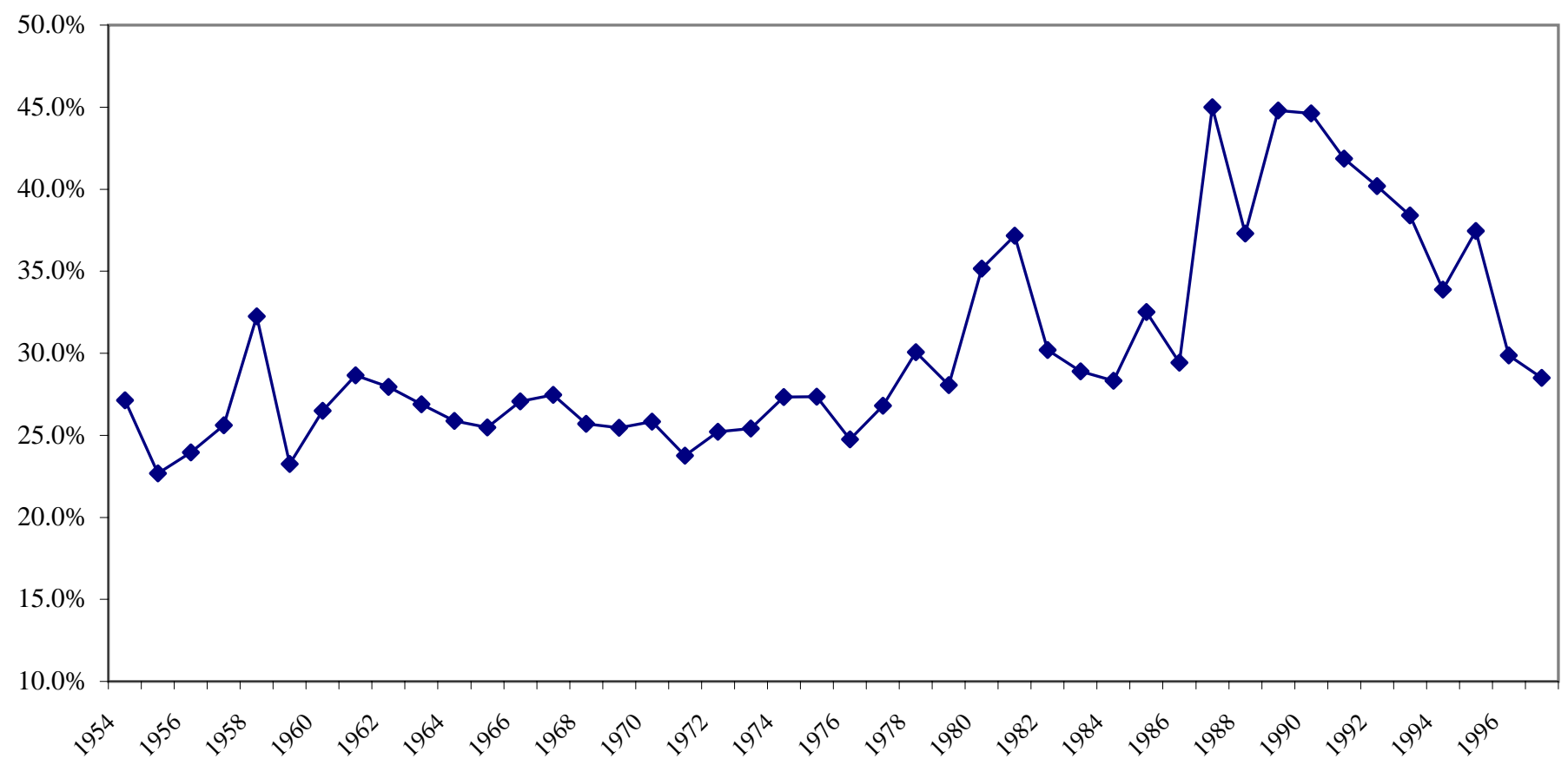

Note: The figure plots the ratio of corporate capital gains to individual capital gains from 1954 to 1997. Corporate capital gains are defined as net long term capital gains reduced by net short term losses for all active corporations.

Figure 2: The Importance of Capital Gains for Individuals and Corporates, 1954-1997

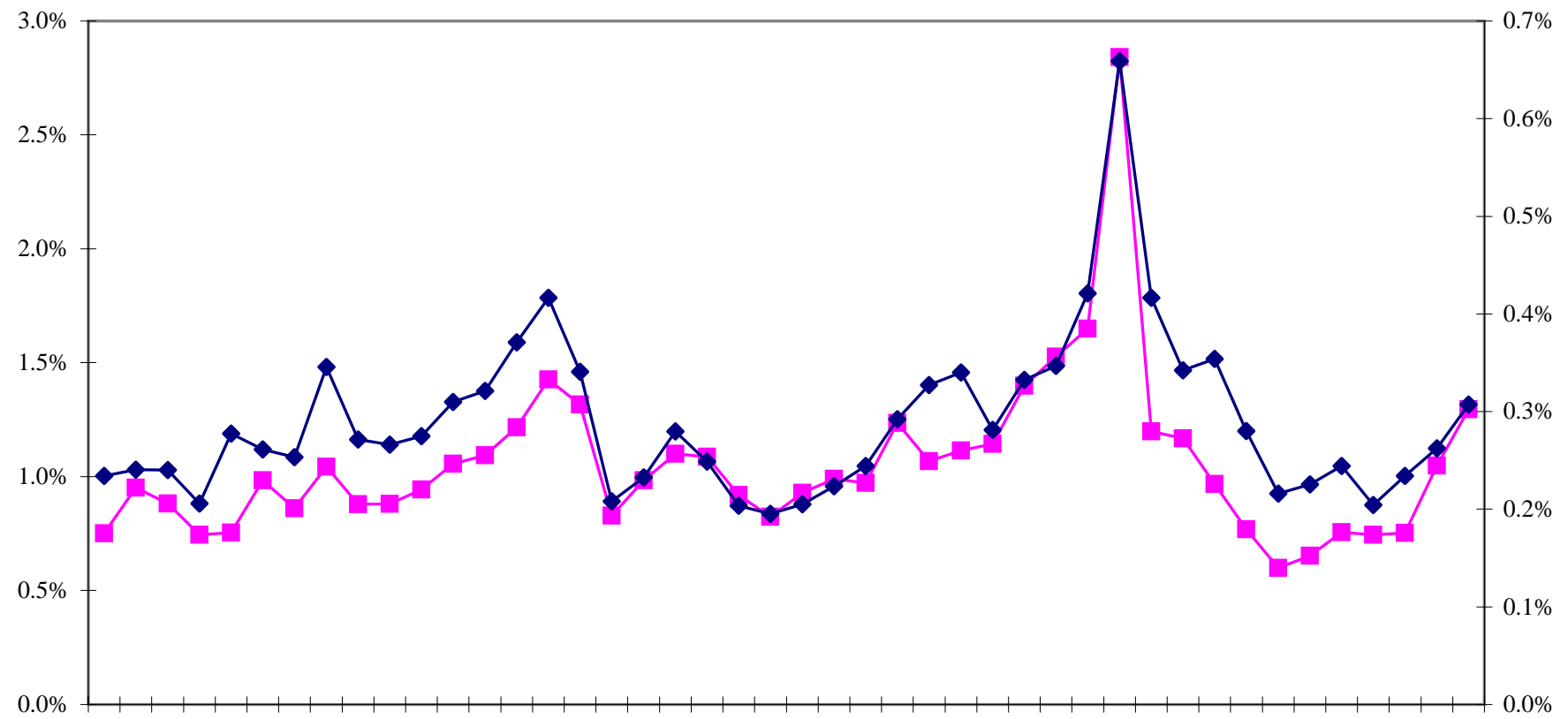

1954195619581960196219641966196819701972197419761978198019821984198619881990199219941996

— Individual Realized Capital Gains as a Share of Household Financial Assets
- Corporate Capital Gains Realizations as a Share of Total Corporate Assets

Note: The figure plots the ratio of realized individual capital gains to household financial assets (on the left axis) and the ratio of realized corporate capital gains to total corporate assets (on the right axis) from 1954 to 1997. Corporate capital gains are defined as net long term capital gains reduced by net short term losses for all active corporations. 
Table 1

The Magnitude and Distribution of Corporate Capital Gains, 1990-1999

\section{The Magnitude of Gain Activity, 1999}

Net Long Term Capital Gains, 1999

Net Short Term Capital Gains, 1999

Net Gains on Noncapital Assets, 1999

\section{All Industries $\quad$ Manufacturing}

Non-Pass Through Entities

All Entities

Non-Pass Through Entities

|Non-Pass Through Entities

$\begin{array}{rrr}146,520,147 & 32,817,607 & 40,658,231 \\ 144,547,184 & 32,817,607 & 38,685,268 \\ 94,913,405 & 3,590,537 & 86,208,324 \\ 14,314,130 & 3,590,537 & 5,609,048 \\ 64,698,446 & 19,372,208 & 8,027,470 \\ 58,284,289 & 18,309,051 & 6,820,218\end{array}$

Other Industries

$73,044,309$

$73,044,309$

$5,114,544$

$5,114,545$

$37,298,768$

$33,155,020$

\section{The Distribution of Economic Activity, 90-99}

Share of Total Assets, 90-99

$18.7 \%$

$56.3 \%$

$25.0 \%$

Non-Pass Through Entities

$21.4 \%$

$49.2 \%$

$29.4 \%$

Share of Total Receipts, 90-99

All Entities

$30.8 \%$

$16.0 \%$

$53.2 \%$

Non-Pass Through Entities

$33.6 \%$

$16.8 \%$

$49.6 \%$

Share of Income Subject to Tax, 90-99

All Entities

$40.8 \%$

$23.3 \%$

$35.9 \%$

Non-Pass Through Entities

$39.9 \%$

$22.8 \%$

$37.3 \%$

\section{The Distribution of Gain Activity, 90-99}

Share of Net Long Term Gains, 90-99

All Entities

$25.7 \%$

$39.6 \%$

$34.7 \%$

Non-Pass Through Entities

$25.7 \%$

$36.6 \%$

$37.7 \%$

Share of Net Short Term Gains, 90-99

All Entities

$3.3 \%$

$91.7 \%$

$4.9 \%$

Non-Pass Through Entities

$15.1 \%$

$60.4 \%$

$24.5 \%$

Share of Net Gains on Noncapital Assets, 90-99

All Entities

$34.4 \%$

$20.4 \%$

$45.3 \%$

Non-Pass Through Entities

Note: The top panel characterizes the magnitude of capital gain activity in 1999 (in thousands of dollars) for all entities and only non-pass through entities in varied industrial groupings. The middle panel characterizes the distribution of economic activity for the 1990s for all entities and only non-pass through entities in varied industrial groupings. The ratios presented in the rows of the middle panel sum to one hundred percent. The bottom panel characterizes the distribution of capital gain activity for the 1990s for all entities and only non-pass through entities in varied industrial groupings. The ratios presented in the rows of the bottom panel sum to one hundred percent. 
Table 2

The Scope of Corporate Capital Gains, Non-Pass Through Entities, 1990-1999

$\underline{\text { All Industries }} \quad \underline{\text { Manufacturing }} \quad \underline{\text { Other Industries }}$

Ratio of Net Long Term Gains to Income

Subject to Tax

$\begin{array}{rrrrr}1990 & 33.5 \% & 21.0 \% & 62.9 \% & 27.4 \% \\ 1991 & 11.7 \% & 7.4 \% & 19.6 \% & 9.2 \% \\ 1992 & 11.9 \% & 7.3 \% & 22.5 \% & 8.6 \% \\ 1993 & 12.2 \% & 8.5 \% & 22.2 \% & 8.0 \% \\ 1994 & 9.6 \% & 8.3 \% & 12.3 \% & 7.8 \% \\ 1995 & 10.8 \% & 7.1 \% & 17.3 \% & 8.5 \% \\ 1996 & 11.7 \% & 8.3 \% & 21.1 \% & 8.4 \% \\ 1997 & 14.7 \% & 10.0 \% & 22.8 \% & 8.4 \% \\ 1998 & 18.7 \% & 9.8 \% & 38.9 \% & 9.9 \% \\ 1999 & 20.9 \% & 13.2 \% & 31.9 \% & 10.3 \%\end{array}$

Ratio of Net Long Term

Gains to Assets

$\begin{array}{lllll}1990 & 0.27 \% & 0.36 \% & 0.16 \% & 0.42 \% \\ 1991 & 0.25 \% & 0.29 \% & 0.17 \% & 0.37 \% \\ 1992 & 0.26 \% & 0.28 \% & 0.24 \% & 0.28 \% \\ 1993 & 0.29 \% & 0.36 \% & 0.27 \% & 0.25 \% \\ 1994 & 0.24 \% & 0.40 \% & 0.13 \% & 0.36 \% \\ 1995 & 0.28 \% & 0.35 \% & 0.21 \% & 0.39 \% \\ 1996 & 0.32 \% & 0.43 \% & 0.27 \% & 0.33 \% \\ 1997 & 0.38 \% & 0.50 \% & 0.27 \% & 0.57 \% \\ 1998 & 0.42 \% & 0.38 \% & 0.43 \% & 0.43 \% \\ 1999 & 0.45 \% & 0.50 \% & 0.31 \% & 0.55 \%\end{array}$

Ratio of All Gains to

Assets

\begin{tabular}{lllll}
1990 & $0.46 \%$ & $0.64 \%$ & $0.26 \%$ & $0.76 \%$ \\
1991 & $0.46 \%$ & $0.54 \%$ & $0.33 \%$ & $0.69 \%$ \\
1992 & $0.47 \%$ & $0.52 \%$ & $0.41 \%$ & $0.58 \%$ \\
1993 & $0.50 \%$ & $0.62 \%$ & $0.44 \%$ & $0.54 \%$ \\
1994 & $0.41 \%$ & $0.67 \%$ & $0.20 \%$ & $0.68 \%$ \\
1995 & $0.50 \%$ & $0.66 \%$ & $0.34 \%$ & $0.75 \%$ \\
1996 & $0.54 \%$ & $0.83 \%$ & $0.37 \%$ & $0.69 \%$ \\
1997 & $0.62 \%$ & $0.92 \%$ & $0.40 \%$ & $0.94 \%$ \\
1998 & $0.67 \%$ & $0.80 \%$ & $0.56 \%$ & $0.70 \%$ \\
1999 & $0.67 \%$ & $0.83 \%$ & $0.41 \%$ & $0.84 \%$ \\
\hline
\end{tabular}

Note: The top panel provides the ratios of net long term gains to income subject to tax for all non-pass through entities throug the 1990s for all industries and selected subindustries. The middle panel provides the ratios of net long term gains to total assets for all non-pass through entities throug the 1990s for all industries and selected subindustries. The bottom panel provides the ratios of all gains to assets for all non-pass through entities throug the 1990s for all industries and selected subindustries. 
Table 3

\section{Descriptive Statistics for Regression Analysis}

Panel A: Times Series Analysis

\begin{tabular}{lcccc} 
& Mean & Median & Std Dev & No Obs \\
Log Deflated Net Long Term Capital & -1.1533 & -1.2068 & 0.6601 & 44 \\
Gains Realizations & & & & 44 \\
Corporate Capital Gains Rate & 0.2882 & 0.2800 & 0.0367 & 49 \\
Log real GNP & 8.4173 & 8.4775 & 0.4640 & 49 \\
Log S\&P 500 Index & 1.2663 & 1.1682 & 0.5286 & 44 \\
Log GNP Deflator & 2.9447 & 2.9313 & 0.4036 & 39 \\
Closed End Fund Discount & 8.8669 & 9.3820 & 8.1197 & 36 \\
Percent of CRSP Value Acquired & $1.22 \%$ & $1.09 \%$ & $0.85 \%$ & 40 \\
Number of IPOs & 352 & 351 & 263 & \\
\hline
\end{tabular}

Panel B: Panel Analysis

\begin{tabular}{lrrrr} 
& \multicolumn{1}{c}{ Mean } & \multicolumn{1}{c}{ Median } & Std Dev & No Obs \\
Sale of Investment Dummy & 0.2587 & 0.0000 & 0.4379 & 91,325 \\
Log Proceeds from Sale of Investments & 1.3975 & 1.2834 & 3.2458 & 23,626 \\
Sale of PPE Dummy & 0.5016 & 1.0000 & 0.5000 & 76,325 \\
Log Proceeds from Sale of PPE & -0.7323 & -0.7012 & 2.7451 & 38,284 \\
Gain Dummy & 0.2627 & 0.0000 & 0.4401 & 67,741 \\
Log Value of Gain & -0.2014 & -0.2231 & 2.8163 & 17,797 \\
Loss Dummy & 0.1851 & 0.0000 & 0.3884 & 67,741 \\
Log Value of Loss & -1.9489 & -2.0636 & 2.5255 & 12,541 \\
Marginal Tax Rates & 0.2074 & 0.2943 & 0.1839 & 100,646 \\
Log Total Assets & 4.6701 & 4.5446 & 2.3820 & 100,646 \\
Log q ratio & 0.4024 & 0.2312 & 0.6546 & 100,646
\end{tabular}

Note: Panel A provides descriptive statistics for the sample employed in the time series analysis presented in Table $4 . \quad$ Panel B provides descriptive statistics for the sample employed in the panel analysis presented in Tables 5 and 6. "Log Deflated Net Long Term Capital Gains Realizations" is the log value of net long term corporate capital gain realizations described in the text. "Corporate Capital Gains Rate" is the applicable corporate capital gains rate over the sample period. "Log S\&P 500 Index" is the log value of the S\&P 500 index over the sample period. "Log GNP Deflator" is the log value of the GNP deflator over the sample period. "Closed End Fund Discount" is the average closed end fund discount over the sample period. "Percent of CRSP Value Acquired" is the share of CRSP value acquired in a given year as presented in Andrade, Mitchell and Stafford (2001). "Number of IPOs" is the number of initial public offerings in a given year. "Sale of Investment Dummy" is a dummy variable equal to one if a corporation reports the sale of investments in a given year. "Log Proceeds from Sale of Investments" is the log value of those sale proceeds. "Sale of PPE Dummy" is a dummy variable equal to one if a corporation reports the sale of PP\&E in a given year. "Log Proceeds from Sale of PPE" is the log value of those sale proceeds. "Gain Dummy" is a dummy variable equal to one if a corporation reports the gain on the sale of investments and PP\&E in a given year. "Log Value of Gain" is the log value of that gain value. "Loss Dummy" is a dummy variable equal to one if a corporation reports the loss on the sale of investments and PP\&E in a given year. "Log Value of Loss" is the log value of that loss value. "Marginal Tax Rates" are calculated via the methodology described in Graham (1996). "Log Total Assets" is the log value of total firm assets. "Log q ratio" is the log of the q ratio calculated from Compustat data as described in the text. 


\title{
Table 4
}

\section{Determinants of Corporate Corporate Capital Gains Realizations, 1954-1998}

\author{
Dependent Variable: Deflated Corporate Capital Gain Realizations
}
(1)
(2)
(3)
(4)
(5)
(6)

1956-1997 $1963-1997 \quad 1963-1997 \quad 1963-1997 \quad 1963-1997 \quad 1963-1997$

\begin{tabular}{|c|c|c|c|c|c|c|}
\hline Constant & $\begin{array}{r}-0.0973 \\
(0.1087)\end{array}$ & $\begin{array}{r}-0.1411 \\
(0.1260)\end{array}$ & $\begin{array}{r}-0.1464 \\
(0.1316)\end{array}$ & $\begin{array}{r}-0.1710 \\
(0.1391)\end{array}$ & $\begin{array}{r}-0.2692 \\
(0.1357)\end{array}$ & $\begin{array}{r}-0.2617 \\
(0.1393)\end{array}$ \\
\hline $\begin{array}{l}\text { Corporate Capital } \\
\text { Gains Rate }\end{array}$ & $\begin{array}{r}-9.2577 \\
(2.6969)\end{array}$ & $\begin{array}{r}-9.0111 \\
(2.8258)\end{array}$ & $\begin{array}{r}-7.8719 \\
(4.0530)\end{array}$ & $\begin{array}{r}-8.9049 \\
(3.0853)\end{array}$ & $\begin{array}{r}-4.1537 \\
(2.9736)\end{array}$ & $\begin{array}{r}-3.9293 \\
(2.9881)\end{array}$ \\
\hline Log real GNP & $\begin{array}{r}3.5385 \\
(2.0995)\end{array}$ & $\begin{array}{r}4.4797 \\
(2.1710)\end{array}$ & $\begin{array}{r}4.6545 \\
(2.1636)\end{array}$ & $\begin{array}{r}5.0439 \\
(2.3573)\end{array}$ & $\begin{array}{r}6.7226 \\
(2.0242)\end{array}$ & $\begin{array}{r}6.5702 \\
(2.0375)\end{array}$ \\
\hline $\begin{array}{l}\text { Lagged Log real } \\
\text { GNP }\end{array}$ & $\begin{array}{r}-0.8293 \\
(1.3772)\end{array}$ & $\begin{array}{r}-0.1636 \\
(1.5463)\end{array}$ & $\begin{array}{r}-0.0614 \\
(1.5283)\end{array}$ & $\begin{array}{r}-0.2418 \\
(1.5204)\end{array}$ & $\begin{array}{r}-2.0807 \\
(1.4875)\end{array}$ & $\begin{array}{r}-2.1513 \\
(1.5956)\end{array}$ \\
\hline Log S\&P 500 Index & $\begin{array}{r}0.7231 \\
(0.2230)\end{array}$ & $\begin{array}{r}0.5973 \\
(0.2283)\end{array}$ & $\begin{array}{r}0.5549 \\
(0.2304)\end{array}$ & $\begin{array}{r}0.6322 \\
(0.2201)\end{array}$ & $\begin{array}{r}0.6268 \\
(0.2189)\end{array}$ & $\begin{array}{r}0.6111 \\
(0.2304)\end{array}$ \\
\hline Log GNP Deflator & $\begin{array}{r}0.8356 \\
(1.4820)\end{array}$ & $\begin{array}{r}1.1678 \\
(1.6930)\end{array}$ & $\begin{array}{r}1.0589 \\
(1.8423)\end{array}$ & $\begin{array}{r}1.4632 \\
(1.7788)\end{array}$ & $\begin{array}{r}2.0007 \\
(1.9352)\end{array}$ & $\begin{array}{r}1.9014 \\
(2.0358)\end{array}$ \\
\hline $\begin{array}{l}\text { Closed End Fund } \\
\text { Discount }\end{array}$ & & & $\begin{array}{r}-0.0048 \\
(0.0066)\end{array}$ & & & \\
\hline $\begin{array}{l}\text { Percent of CRSP Value } \\
\text { Acquired }\end{array}$ & & & & $\begin{array}{r}-3.3062 \\
(3.9924)\end{array}$ & & $\begin{array}{r}1.6430 \\
(5.1817)\end{array}$ \\
\hline Number of IPOs & & & & & $\begin{array}{r}0.0004 \\
(0.0001)\end{array}$ & $\begin{array}{r}0.0004 \\
(0.0002)\end{array}$ \\
\hline No Obs & 42 & 35 & 35 & 35 & 35 & 35 \\
\hline $\begin{array}{l}\text { Note: The columns present sh } \\
\text { gain realizations described in } \\
\text { corporate capital gains rate ov } \\
\text { period. "Log GNP Deflator" } \\
\text { average closed end fund disco } \\
\text { in a given year as presented in } \\
\text { a given year. }\end{array}$ & le period. & $\begin{array}{l}\text { n first diffe } \\
\text { S\&P } 500 \\
\text { deflator or } \\
\text { "Percent } \\
\text { fford (200 }\end{array}$ & $\begin{array}{l}\text { ' is the log } \\
\text { sample pe } \\
\text { SP Value }\end{array}$ & $\begin{array}{l}\text { pital Gai } \\
\text { of the S\& } \\
\text { 'Closed } \\
\text { ed" is th }\end{array}$ & $\begin{array}{l}\text { "is the a } \\
\text { index ov } \\
\text { d Disco } \\
\text { CRSP }\end{array}$ & $\begin{array}{l}\text { te capital } \\
\text { able } \\
\text { sample } \\
\text { the } \\
\text { acquired }\end{array}$ \\
\hline
\end{tabular}


Table 5

Determinants of Corporate Asset Disposal Behavior, 1980-2002

Panel A: Disposal of Investments

\begin{tabular}{|c|c|c|c|c|c|c|}
\hline & Sale Dummy & Sale Dummy & Sale Dummy & $\begin{array}{c}\text { Log Sale } \\
\text { Value }\end{array}$ & $\begin{array}{c}\text { Log Sale } \\
\text { Value }\end{array}$ & $\begin{array}{c}\text { Log Sale } \\
\text { Value }\end{array}$ \\
\hline Marginal Tax Rate & $\begin{array}{r}-0.0459 \\
(0.0090)\end{array}$ & $\begin{array}{r}-0.0400 \\
(0.0092)\end{array}$ & $\begin{array}{r}-0.0402 \\
(0.0097)\end{array}$ & $\begin{array}{r}-0.5111 \\
(0.0991)\end{array}$ & $\begin{array}{r}-0.2778 \\
(0.0949)\end{array}$ & $\begin{array}{r}-0.0452 \\
(0.0985)\end{array}$ \\
\hline Log Total Assets & & $\begin{array}{r}0.0410 \\
(0.0018)\end{array}$ & $\begin{array}{r}0.0396 \\
(0.0021)\end{array}$ & & $\begin{array}{r}0.0618 \\
(0.0372)\end{array}$ & $\begin{array}{r}0.8460 \\
(0.0228)\end{array}$ \\
\hline $\log q$ & & $\begin{array}{r}-0.0028 \\
(0.0031)\end{array}$ & $\begin{array}{r}-0.0044 \\
(0.0032)\end{array}$ & & $\begin{array}{r}0.9378 \\
(0.0191)\end{array}$ & $\begin{array}{r}0.0271 \\
(0.0379)\end{array}$ \\
\hline No Obs & 88,102 & 84,122 & 84,122 & 22,612 & 21,749 & 21,749 \\
\hline No Firms & 12,788 & 12,645 & 12,645 & 5,997 & 5,861 & 5,861 \\
\hline Firm Fixed Effects? & $\mathrm{Y}$ & $\mathrm{Y}$ & $\mathrm{Y}$ & $\mathrm{Y}$ & $\mathrm{Y}$ & $\mathrm{Y}$ \\
\hline Year Fixed Effects? & $\mathrm{N}$ & $\mathrm{N}$ & $\mathrm{Y}$ & $\mathrm{N}$ & $\mathrm{N}$ & $\mathrm{Y}$ \\
\hline
\end{tabular}

Panel B: Disposal of PPE

\begin{tabular}{|c|c|c|c|c|c|c|}
\hline & Sale Dummy & Sale Dummy & Sale Dummy & $\begin{array}{c}\text { Log Sale } \\
\text { Value }\end{array}$ & $\begin{array}{c}\text { Log Sale } \\
\text { Value }\end{array}$ & $\begin{array}{c}\text { Log Sale } \\
\text { Value }\end{array}$ \\
\hline Marginal Tax Rate & $\begin{array}{r}-0.0747 \\
(0.0107)\end{array}$ & $\begin{array}{r}-0.0669 \\
(0.0109)\end{array}$ & $\begin{array}{r}-0.1223 \\
(0.0114)\end{array}$ & $\begin{array}{r}-0.8025 \\
(0.0679)\end{array}$ & $\begin{array}{r}-0.5995 \\
(0.0680)\end{array}$ & $\begin{array}{r}-0.7698 \\
(0.0711)\end{array}$ \\
\hline Log Total Assets & & $\begin{array}{r}-0.0164 \\
(0.0021)\end{array}$ & $\begin{array}{r}0.0072 \\
(0.0025)\end{array}$ & & $\begin{array}{r}0.6160 \\
(0.0160)\end{array}$ & $\begin{array}{r}0.6643 \\
(0.0193)\end{array}$ \\
\hline $\log q$ & & $\begin{array}{r}-0.0387 \\
(0.0036)\end{array}$ & $\begin{array}{r}-0.0290 \\
(0.0036)\end{array}$ & & $\begin{array}{r}-0.1248 \\
(0.0285)\end{array}$ & $\begin{array}{r}-0.1184 \\
(0.0291)\end{array}$ \\
\hline No Obs & 73,530 & 70,023 & 70,023 & 36,724 & 35,213 & 35,213 \\
\hline No Firms & 12,033 & 11,878 & 11,878 & 7,756 & 7,606 & 7,606 \\
\hline Firm Fixed Effects? & $\mathrm{Y}$ & $\mathrm{Y}$ & $\mathrm{Y}$ & $\mathrm{Y}$ & $\mathrm{Y}$ & $\mathrm{Y}$ \\
\hline Year Fixed Effects? & $\mathrm{N}$ & $\mathrm{N}$ & $\mathrm{Y}$ & $\mathrm{N}$ & $\mathrm{N}$ & $\mathrm{Y}$ \\
\hline
\end{tabular}

Note: Panel A presents specifications that analyze investment disposal behavior and Panel B presents specifications that analyze PPE disposal behavior. In both panels, the first three columns employ a dummy variable set equal to one if there is a sale as a dependent variable. In both panels, the second three columns employ the log value of that sale amount as a dependent variable. All columns employ firm fixed effects and columns 3 and 6 of both panels also employ year fixed effects. "Marginal Tax Rates" are calculated via the methodology described in Graham (1996). "Log Total Assets" is the log value of total firm assets. "Log q ratio" is the log of the $q$ ratio calculated from Compustat data as described in the text. 
Table 6

Determinants of Corporate Gain/Loss Realization Behavior, 1986-2002

\section{Panel A: Gain Recognition Behavior}

\begin{tabular}{|c|c|c|c|c|c|c|}
\hline & $\begin{array}{c}\text { Gain } \\
\text { Dummy }\end{array}$ & $\begin{array}{c}\text { Gain } \\
\text { Dummy }\end{array}$ & $\begin{array}{c}\text { Gain } \\
\text { Dummy }\end{array}$ & $\begin{array}{c}\text { Log Gain } \\
\text { Value }\end{array}$ & $\begin{array}{c}\text { Log Gain } \\
\text { Value }\end{array}$ & $\begin{array}{c}\text { Log Gain } \\
\text { Value }\end{array}$ \\
\hline Marginal Tax Rate & $\begin{array}{r}-0.0709 \\
(0.0146)\end{array}$ & $\begin{array}{r}-0.0757 \\
(0.0151)\end{array}$ & $\begin{array}{r}-0.0397 \\
(0.0151)\end{array}$ & $\begin{array}{r}-0.1480 \\
(0.1409)\end{array}$ & $\begin{array}{r}-0.3283 \\
(0.1416)\end{array}$ & $\begin{array}{r}-0.2674 \\
(0.1423)\end{array}$ \\
\hline Log Total Assets & & $\begin{array}{r}0.0376 \\
(0.0027)\end{array}$ & $\begin{array}{r}0.0128 \\
(0.0031)\end{array}$ & & $\begin{array}{r}0.7021 \\
(0.0289)\end{array}$ & $\begin{array}{r}0.5690 \\
(0.0332)\end{array}$ \\
\hline $\log q$ & & $\begin{array}{r}-0.0106 \\
(0.0043)\end{array}$ & $\begin{array}{r}-0.0223 \\
(0.0043)\end{array}$ & & $\begin{array}{r}-0.0416 \\
(0.0533)\end{array}$ & $\begin{array}{r}-0.0760 \\
(0.0542)\end{array}$ \\
\hline No Obs & 65,809 & 62,994 & 62,994 & 17,268 & 16,713 & 16,713 \\
\hline No Firms & 10,815 & 10,658 & 10,658 & 5,757 & 5,618 & 5,618 \\
\hline Firm Fixed Effects? & $\mathrm{Y}$ & $\mathrm{Y}$ & $\mathrm{Y}$ & $\mathrm{Y}$ & $\mathrm{Y}$ & $\mathrm{Y}$ \\
\hline Year Fixed Effects? & $\mathrm{N}$ & $\mathrm{N}$ & $\mathrm{Y}$ & $\mathrm{N}$ & $\mathrm{N}$ & $\mathrm{Y}$ \\
\hline
\end{tabular}

Panel B: Loss Recognition Behavior

\begin{tabular}{|c|c|c|c|c|c|c|}
\hline \multirow[b]{2}{*}{ Marginal Tax Rate } & \multicolumn{3}{|c|}{ Loss Dummy Loss Dummy Loss Dummy } & \multirow{2}{*}{$\begin{array}{l}\begin{array}{c}\text { Log Loss } \\
\text { Value }\end{array} \\
\begin{array}{c}-1.2982 \\
(0.1718)\end{array}\end{array}$} & \multirow{2}{*}{$\begin{array}{l}\begin{array}{l}\text { Log Loss } \\
\text { Value }\end{array} \\
\begin{array}{c}-1.3574 \\
(0.1750)\end{array}\end{array}$} & \multirow{2}{*}{$\begin{array}{l}\text { Log Loss } \\
\text { Value } \\
\begin{array}{c}-1.2516 \\
(0.1761)\end{array}\end{array}$} \\
\hline & $\begin{array}{r}-0.1120 \\
(0.0131)\end{array}$ & $\begin{array}{r}-0.1041 \\
(0.0135)\end{array}$ & $\begin{array}{c}-0.0687 \\
(0.0136)\end{array}$ & & & \\
\hline Log Total Assets & & $\begin{array}{r}0.0073 \\
(0.0024)\end{array}$ & $\begin{array}{r}-0.0075 \\
(0.0028)\end{array}$ & & $\begin{array}{r}0.4345 \\
(0.0354)\end{array}$ & $\begin{array}{r}0.3272 \\
(0.0409)\end{array}$ \\
\hline $\log q$ & & $\begin{array}{r}-0.0215 \\
(0.0038)\end{array}$ & $\begin{array}{r}-0.0243 \\
(0.0039)\end{array}$ & & $\begin{array}{r}-0.1956 \\
(0.0497)\end{array}$ & $\begin{array}{r}-0.2003 \\
(0.0505)\end{array}$ \\
\hline No Obs & 65,809 & 62,994 & 62,994 & 12,000 & 11,581 & 11,581 \\
\hline No Firms & 10,815 & 10,658 & 10,658 & 5,099 & 4,980 & 4,980 \\
\hline Firm Fixed Effects? & $\mathrm{Y}$ & $\mathrm{Y}$ & $\mathrm{Y}$ & $\mathrm{Y}$ & $\mathrm{Y}$ & $\mathrm{Y}$ \\
\hline Year Fixed Effects? & $\mathrm{N}$ & $\mathrm{N}$ & $\mathrm{Y}$ & $\mathrm{N}$ & $\mathrm{N}$ & $\mathrm{Y}$ \\
\hline
\end{tabular}

Note: Note: Panel A presents specifications that analyze gain recognition behavior and Panel B presents specifications that analyze loss recognition behavior. In both panels, the first three columns employ a dummy variable set equal to one if there is a gain or loss as a dependent variable. In both panels, the second three columns employ the log value of that gain or loss amount as a dependent variable. All columns employ firm fixed effects and columns 3 and 6 of both panels also employ year fixed effects. "Marginal Tax Rates" are calculated via the methodology described in Graham (1996). "Log Total Assets" is the log value of total firm assets. "Log q ratio" is the $\log$ of the q ratio calculated from Compustat data as described in the text. 